\title{
Fitoremediasyon Yöntemi İle Topraktaki Ağır Metallerin Giderimi
}

\author{
Mustafa Aybar ${ }^{1, *}$, Ayla Bilgin², Bülent Sağlam \\ ${ }^{1}$ Artvin Çoruh Üniversitesi, Artvin Meslek Yüksekokulu, Ormancılık Bölümü, 08100, Artvin. \\ ${ }^{2}$ Artvin Çoruh Üniversitesi, Mühendislik Fakültesi, Çevre Mühendisliği Bölümü, 08100, Artvin \\ ${ }^{3}$ Artvin Çoruh Üniversitesi, Orman Fakültesi, Orman Mühendisliği Bölümü, 08100, Artvin.
}

\section{Özet}

Günümüzde insan sağlı̆̆ını olumsuz yönde etkileyen önemli faktörlerin bașında çevresel kirlilikler gelmektedir. Hayat standartlarının artması, kentlerdeki hızl nüfus artışı ve bunun yanında sanayinin gelişmesi ile birlikte oluşan atıklar çevreyi olumsuz yönde etkilemektedir. Endüstrivel faaliyetler sonucunda çevreye yayllan kirleticilerin giderilmesi için çeșitli yöntemler kullanılmaktadır. Bu yöntemlerin çoğunda ileri teknolojiler kullanılır. Bu ise yüksek yatırım ve işletme maliyetlerinin yanında yetişmiş eleman ihtiyacını da zorunlu kılar. Gelișmiş ülkeler bu olumsuz koșulları dikkate alarak son yıllarda diğerlerine nazaran daha çevre dostu bir arttma sistemi olan fitoremediasyonu (bitkisel islah sistemleri) gelişstirmişlerdir. Bitkisel uslah olarak da bilinen fitoremediasyon ortamda bulunan kirleticilerin giderilmesinde veya etkisiz hale getirilmesinde çeşitli bitkilerin kullanılması şeklinde tanımlanmaktadır. Diğer ıslah teknolojileri ile karșılaștırıldı̆̆ında fitoremediasyon; yerinde arıtım sağlaması, estetik açıdan memnun edici ve düşük maliyetli olması gibi avantajlara sahiptir. Hardal (Brassicajuncea), Kırmızı Yumak (Festucarubra), Karahindiba (Taraxacumofficinale) gibi hiperakümülatör bitkiler ağır metalleri bünyelerinde tutup gaz formuna dönüstürerek doğava saldıkları bilinmektedir. Bu çalışmada, toprak kirliliğinin giderilmesinde kullanılabilecek fitoremediasyon teknolojisi, bitki türleri ve ülkemiz açısından uygulanabilirliği ortaya konulmaktadır.

\section{Anahtar Sözcükler}

Çevresel Kirlilik, Fitoremediasyon, Hiperakümülatör

\section{Removing Heavy Metals from the Soil with Phytoremediation}

\begin{abstract}
Environmental pollution is one of the most critical factors adversely affecting human health. Improvement in living standards, the rapid increase of urban populations, and widespread industrial production, all result in the generation of huge amounts of environment-polluting waste. Various methods are used to remove the pollutants generated by industrial activity but most of these methods require advanced technologies, involving a large financial investment and qualified personnel. Taking these costs and overheads into consideration, some economically developed countries have recently started working with phytoremediation (plantbased remediation) which, compared with the alternatives, is a much more environment-friendly waste treatment system. Also known as plant-based remediation, phytoremediation is defined as the use of various plants to stabilize or reduce contamination in the environment. Compared with other remediation technologies, phytoremediation offers the advantages of on-site treatment, aesthetic value, and low costs. Hyperaccumulators such as Indian Mustard (Brassica juncea), Red Fescue (Festucarubra), and Dandelion (Taraxacum officinale) are known to absorb heavy metals, releasing them into the atmosphere in the form of gas. This study examines phytoremediation technology, the plant species that could be used for this purpose, and the feasibility of using phytoremediation in Turkey.
\end{abstract}

$\underline{\text { Keywords }}$

Environmental Pollution, Phytoremediation, Hyperacommutator

\section{Giriş}

Dünyada ve ülkemizde son yıllarda ciddi bir problem olarak görülen toprak kirliliği, katı, sıvı ve radyoaktif atıkların, toprağın fiziksel ve kimyasal özelliklerini bozmasıdır. Bu bozulmaya neden olan önemli etkenlerin başında ağır metaller gelmektedir. $\mathrm{Bu}$ metaller, ekolojik dengenin bozulmasında, canlıların gelişimlerinde önemli rol oynayan ve çevre kirliliğine neden olan temel etkenlerin başında gelmektedir. Bakır $(\mathrm{Cu})$, çinko $(\mathrm{Zn})$, demir $(\mathrm{Fe})$, manganez (Mn), molibden (Mo), nikel (Ni), kobalt (Co) gibi metaller hayvan ve bitkilerin büyüme ve gelişimlerinde önemli derecede rol oynayan mikro besin elementleridir. Bunun yanında arsenik (As), civa ( $\mathrm{Hg}$ ), kadmiyum $(\mathrm{Cd})$ ve kurşun $(\mathrm{Pb})$ gibi bazı ağır metaller ise canlıların gelişimi için önem arz etmeyen elementlerdir (Niess 1999). Bitkiler için gerekli besin elementleri olsun ya da olmasın ağır metallerin, doğada bulunma oranının belirlenen düzeyin üstüne çıkması durumunda önemli derecede sorunların oluştuğu bilinmektedir (Benavides 2005). Aynı zamanda ağır metallerin toprakta bulunma yüzdesinin üzerine çıkması durumda toprak kalitesinde bozulma ve ürünlerin verim ve kalitelerinde

* Sorumlu Yazar: Tel: +90 (466) 2151000 Faks: +90 (466) 2127532

E-posta: mustafaaybar@artvin.edu.tr (Aybar M), ayla.bilgin@artvin.edu.tr (Bilgin A), bsaglam@artvin.edu.tr (Sağlam B) 
azalmalar meydana gelmekte (Long vd. 2002) bunun sonucunda da insan ve diğer canlılar için ciddi problemler oluşmaktadır (Blaylock ve Huang 2000).

Ağır metaller küresel kirlilik faktörü olarak tüm canlılar üzerinde büyük tehlike oluşturmaktadır. Ağır metaller, insanlar tarafından maruz kalınan doz oranı, kişinin bağışıklık ve genel sağlık durumu gibi çeşitli faktörlere bağlı olarak insanlarda başta kanser olmak üzere birçok hastalığın başlama ve ilerlemesinde etken olmaktadır (Kabata-Pendias ve Dudka 1991).

Ağır metallerle kirlenmiş alanların iyileştirilmesinde kullanılan pahalı ve daha fazla uğraş gerektiren geleneksel mühendislik yöntemleri olan remediasyon teknikleri (Salt vd. 1995; Glass 2000) yerine son y1llarda maliyeti daha düşük teknik, çevre dostu olan yeşil ıslah (fitoremediasyon) teknolojisi kullanılmaktadır (Arshad vd. 2008; Shi vd. 2009).

Fitoremediasyon tekniğinde genellikle hiperakümülatör bitkiler kullanılmaktır. Bu bitkiler; yaprak dal ve gövdelerinde toprakta bulunan metal oranından 50 ila 500 kat daha fazla metal biriktiren bitkilerdir (Clemens 2006). Diğer bir deyişle, bu bitkiler toprağın üstünde bulunan organları ile hiperakümülator olamayan bitkilere nazaran 100 ila 1000 kat daha fazla organik madde bulundurabilirler (Brooks 1998). Çiçekli bitkilerin \%0.2'sini oluşturan hiperakümülatör bitkiler yaklaşık olarak 450 tanedir (Baker ve Brooks 1989; Ellis ve Salt 2003; Reeves 2006; Milner ve Kochian 2008).

Bu çalışma kapsamında hiperakümülatör bitkiler kullanılarak topraktaki ağır metallerin fitoremediasyon yöntemi ile giderilmesi, bu yöntemin kullanım alanlarının yanında yöntemin avantaj ve dezavantajları ele alınmıştır.

\section{Fitoremediasyonun Tanımı}

Fitoremediasyon tekniğinde çevresel kirleticiler kapsamında ağır metalleri absorbe eden, dokularında yüksek seviyelerde biriktirip çeşitli süreçlerden sonra etkisiz hale getirebilen hiperakümülatör bitkiler kullanılmaktadır.

Son yıllarda birçok ülkede kullanımı yaygınlaşan fito-ıslah, ağır metallerle kirlenmiş toprakların temizlenmesinde pasif bir teknolojidir. Fitoremediasyon, çevredeki kirleticilerin alınmasında veya bu kirleticilerin etkisiz hale getirilmesinde hiperakümülatör bitkilerin kullanılması olarak tanımlanır (Raskin vd. 1997). Farklı 1slah yöntemleriyle kıyaslandığında oldukça düşük masraflı, estetik olarak memnun edici olmasıyla beraber uygulama kolaylığı ve uygulama süresinin kısalı̆̆1 gibi birçok avantaja sahiptir (Glass 1999).

Yeşil 1slah, düşük ve orta risk grubundaki kirlenmiş yerlerin 1slah edilmesinde özellikle seçilmiş, genetik olarak ayarlanmış bitkiler kullanılarak etkili ve memnun edici bir ıslah yöntemi olarak kabul edilmektedir. Bu sslah yöntemi diğer metotlarla birlikte bir tamamlama evresi olarak da kullanılabilir.

Ağır metallerle kirlenmiş alanlarda kullanılan fito-1slah metotları ile organik kirleticiler ile kirlenmiş sahaların iyileştirilmesi için kullanılan metotlar arasında bazı farklar bulunmaktadır. Metallerle kirlenmiş sahalarda bitkiler tarafından absorbe edilen ağır metaller ya toprakta birikerek sabit hale geçerler ya da topraktan uzaklaştırılırlar. Thlapsi, Urtica, Taraxacumofficinale, Chenopodium, Polygonumsachalase ve Allyssim gibi bazı hiperakümülatör bitkiler kadmiyum, bakır, kurşun, nikel ve çinko gibi ağır metalleri bünyelerinde biriktirme yeteneklerine sahiptirler. Bu yüzden, söz konusu bitkilerin yetiştirilmesi kirlenmiş toprakların arıtılmasında dolaylı bir metot olarak kabul edilmektedir (EPA 1995). Örneğin, doğada bulunan bitlkilerin çoğu yaklaşık 100 ppm'lik bir çinko (Zn) birikimi yaptıkları halde, en yaygın hiperakümülatör bitki olarak bilinen Thlapsicaeruledcens'ın 26000 ppm'in üzerinde bir birikim sağladığ farklı kaynaklarda ifade edilmektedir (Lasat 2000).

\section{Fitoremediasyon Tipleri}

Fitoremediasyon teknolojileri kirletici çeşitlerine göre sınıflandırılmıştır. Bu kirleticiler metal içerikli ise; fitoekstraksiyon, fitostabilizasyon ve rizofiltrasyon, organik kirleticiler ise; fitodegradasyon, rizodegradasyon ve fitovolatilizasyon olmak üzere altı farklı sınıfa ayrılmıştır (Tablo 1).

Tablo 1: Fitoremediasyon Teknolojilerinin Kirletici Çeşitlerine Göre Sınıflandırılması

\begin{tabular}{|c|c|}
\hline Metal Kirleticilerde Kullanılan Yöntemler & Organik Kirleticilerde Kullanılan Yöntemler \\
\hline Fitoekstraksiyon & Fitodegradasyon \\
\hline Rizofiltrasyon & Rizodegradasyon \\
\hline Fitostabilizasyon & Fitovolatilizasyon \\
\hline
\end{tabular}

\subsection{Fitoekstraksiyon (Fitoakümülasyon)}

Fitoekstraksiyon, toprakta kirliliğe yol açan metal kirleticilerin bitki kökleri yardımı ile alınması yöntemine verilen isimdir. Bitkiler topraktaki zararlı maddeleri bünyelerine alma konusunda farklı özellikler gösterirler. Bu nedenle kirleticilerin yüksek seviyelerine direnen bitkiler kullanılmalıdır. Bu durum kirlilik oranı yüksek yerlerde büyük önem arz etmektedir. Yüksek kirlilik seviyesine ulaşmış alanlara dayanıklılık gösteren hiperakümülatör bitkiler aynı zamanda absorbsiyon oranının da yüksek olması nedeniyle daha çok tercih edilen türler arasındadır. Kirliliği istenilen seviyelere indirgemek için fitoakümülasyon yöntemi sıklıkla tekrarlanmaktadır. Bazı durumlarda fitomining olarak da bilinen 
yöntem yardımı ile metallerin yeniden işlenerek geri kazanılabilmesi sağlanmaktadır. Bu yöntem değerli metallerin işlenmesinden ayrı tutulur. Çinko, bakır ve nikel gibi ağır metal içerikli bileşikler başarılı bir şekilde fitoekstrakte edilebilmektedirler. Bitkiler bu zararlı metalleri kökleri yardımı ile topraktan alırlar ve diğer vejetatif organlara dağıtımında görev alırlar. Bu nedenle, uygulamada metalleri bünyesinde barındırabilen hiperakümülatör bitkiler kullanılmaktadır. Daha sonra ağır metalleri tutan bitkiler hasat edilir ve yakma fırınlarında yakılırlar veya başka uygun bir metot ile farklı işlemlere tabi tutulurlar (EPA 1995).

Fitoekstraksiyon yönteminin başarısı bitkilerin biyokütle üretme hızına ve alınan metalleri gövde dokularında yüksek miktarlarda absorbe edebilme yeteneğine bağlıdır (Blaylock ve Huang 2000). Bu yönteme uygun hiperakümülatör bitkilerinin seçilmesi, bitki ıslahı ve genetik yöntemler kullanılarak hiperakümülatör bitkilerin geliştirilmesi fitoremediasyon teknolojilerinin geliştirilmesinde kullanılan önemli stratejilerdendir.

\subsection{Rizofiltrasyon}

Rizofiltrasyon yönteminde diğer yöntemlere nazaran kullanılacak bitkilerde filtre görevi yapan iyi gelişmiş bir kök sistemine ihtiyaç duyulmaktadır. Bu yöntemde toprağın ıslahından çok kirlenmiş sudaki ağır metallerin alandan uzaklaştırması uygulanmaktadır. Kirleticiler ya bitkilerin kök yüzeylerinde absorbe edilir ya da kökler aracılığı ile emilerek bitkinin diğer organlarına taşınır. Rizofiltrasyon yöntemi için tercih edilecek hiperakümülatör bitkiler direkt olarak alana ekilmeden önce farklı bir ortamda kirleticiye adaptasyonu sağlanır. Bitkilerin kökleri istenilen düzeyde gelişene kadar toprak yerine temiz suda bekletilmesi tercih edilir. Daha sonra bu gelişmiş kök sistemli bitkiler adaptasyon amaçlı kirlenmiş bir su kaynağına aktarılır. Son olarak bitkilerin uyum sorunu ortadan kalktıktan sonra rizofiltrasyon yöntemini uygulayacağımız kirlenmiş alana dikim işlemi gerçekleştirilir. Kökler doygun hale geldikten sonra hasat işlemine başlanılır ve güvenli bir şekilde imhası gerçekleştirilir (EPA 1995).

\subsection{Fitostabilizasyon}

Fitostabilizasyon genellikle erozyonun meydana geldiği sahalarda erozyonu önlemek amacıyla, yer altı sularına kirleticilerin sızmasını engellemek ve toprakla doğrudan temasını engellemek için kullanılır. Bu yöntem için toprak yüzeyi alana uygun olan hiperakümülatör bitkiler ile örtülmektedir (Bert vd. 2005). Fitostabilizasyon yöntemi ile bitkiler kökler vasıtası ile kirleticileri fiziksel ve kimyasal olarak sabitlerler (Berti ve Cunningham 2000). Bu yöntem için, ağır metallerle kirlenmiş topraklarda büyüyüp gelişebilen ve toksik metalleri daha az toksik formlarına dönüştürebilmek için toprağın fiziksel, kimyasal ve biyolojik özelliklerini değiştirebilen bitkilere ihtiyaç duyulmaktadır. Aynı zamanda fitostabilizasyon yönteminde kullanılacak bitkilerin geniş kök sistemleri olmalı ve yüksek konsantrasyonlardaki metallerle orantılı bir şekilde biyokütle üretebilmelidirler (Rizzi vd. 2004).

$\mathrm{Bu}$ yöntem daha çok toprak, sediment ve çamurların 1slah edilmesinde kullanılır. İyileştirme çalışmaları kapsamında $\mathrm{As}, \mathrm{Cd}, \mathrm{Cr}, \mathrm{Cu}, \mathrm{Hg}, \mathrm{Pb}, \mathrm{Zn}$ gibi elementlerle kirlenmiş topraklarda hibrit kavaklar ve Hindistan hardalı gibi bitkilerin yapılan çalışmalar sonunda başarılı bir şekilde kullanıldığı görülmüştür (EPA 2000).

\subsection{Fitodegradasyon}

Fitodegradasyon metodunda hiperakümülatör bitkiler kullanılarak ortamda bulunan organik kirleticilerin yapısı bozunur ve aynı zamanda ayrıştırma yeteneğine sahip olurlar. Bu oluşumun gerçekleşmesi için enzimatik reaksiyonlar gerçekleşmesi gerekir. Yani bazı kirleticiler ilk önce bitkiler tarafından absorbe edilir ve daha sonra enzimler yardımı ile bozunuma uğratılırlar. Bitkiler tarafından bünyesinde tutulan organik bileşikler metabolik mekanizmalar vasıtasıyla daha küçük parçalara ayrılırlar. Parçalara ayrılan bu moleküller daha sonra da bitkiler tarafından metabolik olarak ayrıca kullanılabilir duruma gelip bitki dokuları ile birleşmiş bir hal alırlar.

$\mathrm{Bu}$ yöntem kullanılarak yeraltı sularındaki çözücüler, topraktaki petrol ve aromatik bileşikler ve havadaki uçucu bileşikler gibi birçok farklı kirletici 1slah edilebilir (Newman ve Reynolds 2004). Bununla beraber bitki enzimleri, cephane atıkları ve ayrıca organik herbisitler gibi bozunabilen diğer zararlı maddelerin arıtımında da bu yöntem kullanılmaktadır (Mirsal 2004).

\subsection{Rizodegradasyon}

$\mathrm{Bu}$ yöntemin çalışma mekanizması, bitkilerin toprak mikroorganizmaları ile birlikte çalışarak organik kirleticileri etkisiz hale getirmesidir. Organizmaların enerji gereksinimlerini karşılamak için ihtiyaç duyduğu besinleri üreten mikroorganizmalar, kök sistemi yardımı ile kirlilik materyallerinin kimyasal yapılarında değişim meydana getirirler. Bu birliktelik yaşamsal faaliyetlerini sürdürebilmek için mikroorganizmaları optimal düzeyde tutar ve toksik kirleticilerin devamlı bir parçalanmasını sağlar. Bu sayede toprakta bulunan mikroorganizmalar, yakıtlar ve solventler gibi organik kirleticileri parçalayıp kendi bünyelerinde biriktirirler.

Bitki kökü şekerler, alkoller ve organik asitleri toprak mikroflorası için karbonhidrat kaynakları olarak harekete geçirirler, mikrobiyal oluşumu ve aktiviteyi arttırırlar. Rizodegradasyonun en önemli yararlarından biri de kirleticilerin 
doğal ortamlarında yok olmalarıdır. Olumsuz yönü ise az miktarda da olsa bitki veya atmosfere taşınmalarıdır (Söğüt vd. 2004). Kökle bozunum yöntemi kullanılarak alandan uzaklaştırılan kirleticiler arasında, TPH (toplam petrollü hidrokarbonlar), PAH (çok halkalı aromatik hidrokarbonlar), BTEX (benzen, toluen, etilbenzen, ksilen), pestisitler (herbisit, insektisit vb.), PCP (pentaklorofenol), PCB (poliklorinatlıbifeniller), yüzey aktif maddeler LAS (lineer alkilbenzensülfonat) sayılabilir. Ayrıca bitki kökleri toprağı gevşeterek mikrobiyal aktivitenin artmasını da sağlarlar (Mirsal 2004)

\subsection{Fitovolatilizasyon}

Bitkisel buharlaştırma olayı organik kirleticiler ve ağır metal içeren suyun büyük bir miktarını kökler vasıtası ile bünyesine alan ağaçlarda meydana gelir. Fitovolatilizasyon yöntemi ile bitkiler tarafından tutulan kirleticiler daha az uçucu formlara dönüştürülerek transpirasyon yolu ile doğaya salınmaktadır. Bilindiği gibi su, köklerden alınarak gövde ve yapraklara iletilirler. Böylece kirleticiler, bitkiyi çevreleyen havaya terleme ve gaz formuna dönüşerek karışır. Daha önce bu çalışma kavak ağaçlarında uygulanıp başarılı sonuçlar alınmıştır (Ghosh ve Singh 2004). Bu yöntemde kökün inebildiği derinlik çok önemlidir. Yer altı sularının ıslahı söz konusu ise derin kök yapabilen bitkiler seçilmelidir. Kirli yer altı suları pompalarla yüzeye çıkarılarak suyun daha sı̆̆ bitki köklerince alınması da farklı bir yöntemdir. Yöntemin en önemli avantajlarından biri civalı bileşikler gibi çok zehirli bileşiklerin daha az zehirli formlara dönüştürülebilmesidir. Fitovolatilizasyon yönteminin başarılı bir şekilde uygulandığı alanlar yeraltı suları başta olmak üzere toprak, çamur ve sediment gibi yerlerdir (Şekil 1) (EPA 2000).

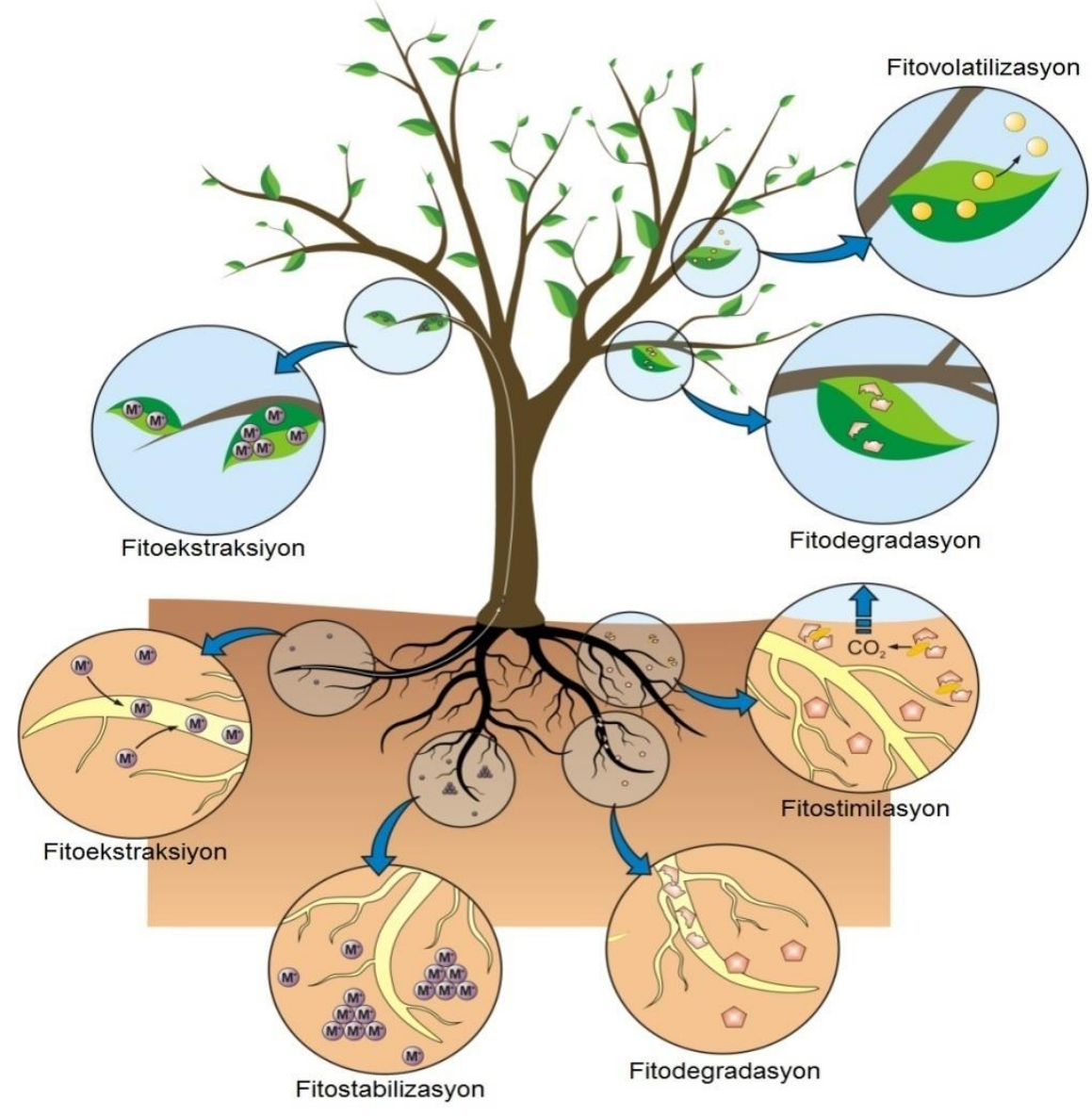

Şekil 1: Fitoremediasyon Tiplerinin Şematik Gösterimi (Favas vd. 2014)

\section{Fitoremediasyonun Kullanım Alanları}

Son yıllarda yaygın olarak kullanılmaya başlayan yeşil ıslah (fitoremediasyon) çalışmaları çok farklı metal ve organik kirleticiler için birçok farklı ülkede denenmiş ve başarılı sonuçlar elde edilmiştir. Aşağıdaki tabloda (Tablo 2) farklı ülkelerde uygulanmış fitoremediasyon sınıflarına göre kirleticilerin bulunduğu ortamlar ve kullanılan bitki türleri verilmiştir (Türkoğlu 2006). 
Tablo 2: Fitoremediasyon tekniklerinin farklı kirletici ve ortamlarda kullanım alanları (Hamutoğlu 2012)

\begin{tabular}{|c|c|c|c|c|}
\hline Mekanizma & Ortam & Süreç Hedefi & Kirleticiler & Bitkiler \\
\hline Fitoekstraksiyon & $\begin{array}{l}\text { Toprak, sediment } \\
\text { ve çamur }\end{array}$ & $\begin{array}{l}\text { Kirletici alma ve } \\
\text { uzaklaştırma }\end{array}$ & $\begin{array}{l}\text { Metaller, } \\
\text { metalloidler ve } \\
\text { radyonükleidler }\end{array}$ & $\begin{array}{l}\text { Hindistan hardalı, } \\
\text { alyssum, ay çiçeği, } \\
\text { hibrit kavaklar }\end{array}$ \\
\hline Rizofiltrasyon & $\begin{array}{l}\text { Yüzey ve yer altı } \\
\text { suyu }\end{array}$ & $\begin{array}{l}\text { Kirletici alma ve } \\
\text { uzaklaştırma }\end{array}$ & $\begin{array}{l}\text { Metaller, } \\
\text { radyonükleidler }\end{array}$ & $\begin{array}{l}\text { Ay çiçeği, } \\
\text { Hindistan } \\
\text { hardalı, su sümbülü }\end{array}$ \\
\hline Fitostabilizasyon & $\begin{array}{l}\text { Toprak, sediment } \\
\text { ve çamur }\end{array}$ & $\begin{array}{l}\text { Kirletici } \\
\text { etkisizleştirme }\end{array}$ & $\begin{array}{l}\mathrm{As}, \mathrm{Cd}, \mathrm{Cr}, \mathrm{Cu}, \mathrm{Hs}, \\
\mathrm{Pb}, \mathrm{Zn}\end{array}$ & $\begin{array}{l}\text { Hindistan hardalı, } \\
\text { Hibrit kavaklar, } \\
\text { çimler }\end{array}$ \\
\hline Rizodegredasyon & $\begin{array}{l}\text { Toprak, yer altı } \\
\text { suyu }\end{array}$ & Kirletici giderme & Organik bileşikler & Kırmızı dut, çimler \\
\hline Fitodegredasyon & $\begin{array}{l}\text { Toprak, sediment } \\
\text { ve çamur, yer altı } \\
\text { suyu, yüzey suyu }\end{array}$ & Kirletici giderme & $\begin{array}{l}\text { Organik bileşikler, } \\
\text { Klorinat çözücüler, } \\
\text { Herbisitler, Fenoller }\end{array}$ & $\begin{array}{l}\text { Alg, Hibrit } \\
\text { kavaklar, } \\
\text { siyah söğü, servi }\end{array}$ \\
\hline Fitovolatilizasyon & $\begin{array}{l}\text { Toprak, sediment } \\
\text { ve çamur, yer altı } \\
\text { suyu }\end{array}$ & $\begin{array}{l}\text { Kirleticiyi } \\
\text { buharlaştırma }\end{array}$ & $\begin{array}{l}\text { Klorinat çözücüler, } \\
\mathrm{Baz} \text { inorganikler } \\
(\mathrm{Se}, \mathrm{Hg}, \mathrm{As})\end{array}$ & $\begin{array}{l}\text { Kavaklar, yonca, } \\
\text { Hindistan hardalı }\end{array}$ \\
\hline
\end{tabular}

\section{Fitoremediasyon Yöntemiyle Ağır Metal Giderimi}

Fitoremediasyon yöntemi ile hiperakümülatör bitkiler tarafından topraktan alınabilme potansiyeline sahip kirleticiler kendi aralarında; metaller (Ag, Cd, Co, Cr, Cu, Hg, Mn, Mo, Ni, Pb, Zn), metalloidler (As,Se), radionükleidler (90Sr, 137Cs, 239Pu, 238U, 234U), ametaller (B) ve diğer organik bileşikler (TPH, PAHs, Pestisitler, PCBs) olmak üzere birçok maddeyi içermektedir. Ancak bitkiler tarafından organik kirleticiler veya ağır metallerin topraktan alınabilmesi için öncelikli olarak ekolojik şartların bitkiler için optimal düzeyde olması gerekmektedir. Bununla birlikte diğer edafik ve biyotik faktörlerin de uygun olması gerekir. Diğer taraftan topraktaki ağır metalleri alma gücü yüksek olan bitkilerin, genellikle lokal olarak yayılış gösterdikleri ve kendilerine has bir yaşam şartlarının olduğu belirlenmiştir. Ancak çok geniş alanlarda yayılış gösterebilen ve fitoremediasyon tekniğinde kullanılabilen bitkiler de mevcuttur (EPA 2000). Buna örnek olarak Taraxacum officinale (Karahindiba) bitkisini verebiliriz.

Bitki kökleri yardımı ile topraktan alınan ağır metallerin bir kısmı, bitki bünyesindeki enzimler aracılığı ile bozunmakta ve kimyasal formlarını değiştirmekte, bir kısmı topraktan aldığı kirleticileri transpirasyon yardımı ile atmosfere salınmakta ve diğer kısmı ise herhangi bir bozunuma uğramayıp bitkinin vejetatif organlarında birikerek, bitkinin hasadıyla ortamdan uzaklaştırılmaktadır (URL-1 2006).

\section{Fitoremediasyon Yönteminin Avantajları ve Dezavantajları}

Fitoremediasyon yöntemi ile kirleticilerin ıslahı yeni bir teknoloji olmakla birlikte birçok avantajı ve dezavantajı bulunmaktadır. Çevresel ıslah adı altında diğer ıslah yöntemleriyle kıyaslandığında bu etmenler daha da anlaşılır hale gelecektir.

Fitoremediasyonun Avantajları;

- Diğer 1slah teknolojilerine göre daha ekonomiktir,

- Sahayı tekrar istila etmede yeni bir bitki topluğuna gerek duyulmaz,

- Atık dökümü için ekstra bir sahaya ihtiyaç duyulmaz,

- Diğer metotlarla kıyaslandığında halk tarafından da kabul gören estetik bir görünüm meydana gelir ve memnun edicidir,

- Yerinde ıslah özelliği ile kirlenmiş alanın başka bir yere taşınmasına gerek kalmadan kirleticilerin yayılması engellemiş olur,

- Tek tip kirleticinin dışında birçok kirleticiyle aynı anda mücadele edilerek alanın ıslahı sağlanabilir.

Fitoremediasyonun Dezavantajlari;

- Başarıya ulaşma hızı alanda kullanılacak bitkilerin, alanın edafik ve biyotik faktörlerine uyum sağlamasıyla birlikte bitkinin kirleticiye olan direncine bağlıdır,

- Yapraklarda biriken kirleticiler sonbaharda yaprak dökümüyle beraber tekrar toprağa karışabilir,

- Yakacak odun olarak kullanılan bitkilerin dokularında kirletici birikmiş olabilir,

- Diğer ıslah metotlarıyla kıyaslandığında ıslah zamanı daha uzun sürebilir,

- Kirleticilerin çözünerek yıkanma sonucu toprağa karışma ihtimali artabilir (EPA 1995). 


\section{Sonuçlar}

Fitoremediasyon teknolojisi, kirleticiler içerisinde ağır metaller ve organik kirleticilerle kirlenmiş toprak ve su kaynaklarının ıslah edilmesi için kullanılan bir yöntemdir. Hiperakümülatör bitkiler, kirlenmiş alanların ıslahı için kullandığından dolayı son yıllarda kullanım alanları artmaktadır. Bitkisel 1slah teknolojisindeki olumsuzluklar genellikle tercih edilen hiperakümülatör bitkilerin çoğunun hem düşük biyokütleye sahip olmaları hem de olumsuz çevre koşullarına uyum sağlamakta güçlük çekmesinden kaynaklanmaktadır. Bu gibi sorunları çözebilmek için bitkilerdeki metal hiperakümülasyonu ile ilişkili mekanizmaların iyi bir şekilde araştırılıp incelenmesi gerekir (Terzi ve Yildiz 2011).

Ağır metallerin bitkiler tarafından absorbe edilmesi, taşınması ve bünyelerinde alıkoyulma mekanizmaları ile ilgili bilgilerin elde edilmesi bu yöntem için transgenik bitkilerin gelişimine önemli katkı sağlamaktadır. Fitoremediasyon için kullanılacak bitkilerdeki gen veya proteinlerin proteomik ve genomik teknolojileri ile araştırılması sonucunda elde edilecek veriler sayesinde ağır metaller ve organik kirleticilerle kirlenmiş sahaların ıslahı için alternatif bitkilerin geliştirilmesi önem arz edecektir.

Toprak kirliliği açısından en önemli çevre kirleticilerinin başında gelen ağır metallerin sslahında tercih edilen fiziksel ve kimyasal arıtma yöntemlerinin, yüksek maliyetli olmaları, arıtım işleminin daha uzun sürmesi ve arıtım sonunda biriken kirletici artıkların imhasındaki sorunlardan dolayı fazla tercih edilmemektedir. Bu amaçla fiziksel, kimyasal ve biyolojik süreçler aracıllğıyla detoksifiye eden bitkilerin kullanılması sonucu ağır metal ve diğer bir kısım kirleticilerin sslah edilmesi olarak tanımlanan yeşil ıslah (fitoremediasyon) yöntemi ise hem ekonomik olması hem de ekolojik olarak kullanılması sebebiyle diğer sslah teknolojilerinden daha yaygın olarak kullanılan bir yöntem olmuştur.

Yeşil ıslah kapsamında uygulamaya konulan birçok farklı yöntem ve uygulamada kullanılacak alternatifli bitki türlerinin bulunması, fitoremediasyon teknolojinin kullanım olanağını arttırmaktadır. Fakat şu da bilinmelidir ki bu yöntemin, ilk aşamada kirleticileri nihai olarak uzaklaştırma veya giderme yöntemi olarak değerlendirilmemesi gerekir. Nihai giderim işlemi fitoremediasyon işlemi sonunda ağır metal birikimi olmuş bitki kök, gövde veya yaprakların ıslah edilmesi kapsamında yakılarak, uygun özelliklere sahip ise hayvanlar için yem bitkisi olarak kullanılarak veya uygun bir alanda depolanarak başarılı bir sonuç elde edilebilir.

\section{Kaynaklar}

Arshad M., Silvestre J., Pinelli E., Kallerhoff J., Kaemmerer M., Tarigo A., (2008), A field study of lead phytoextraction by various, Scented Pelargonium Cultivars, Chemosphere, 71, 2187-2192.

Baker A.J.M., Brooks R.R., (1989), Terrestrial higher plants which hyperaccumulate metallic elements-a review of their distribution, Ecology and Phytochemistry, Biorecovery, 1, 81-126.

Benavides M.P., Gallego S.M., Tomaro M.L., (2005), Cadmium toxicity in plants, Brazilian Journal of Plant Physiology, 17(1), 2134.

Bert V., Girondelot B., Quatannens V., Laboudigue A., (2005), A phytostabilisation of a metal polluted dredged sediment depositMesocosm experiment and field trial, Proceedings of the 9th International FZK/TNO Conference on soil-water systems remediation concepts and technologies'in İçinde, (Uhlmann O., Annokkée G.J., Arendt F. eds), Bordeux, ss.1544-50.

Berti W.R, Cunningham S.D., (2000), Phytostabilization of Metals, Phytoremediation of Toxic Metals: Using Plants to Clean-up the Environment'1n içinde, (Raskin I., Ensley B.D., Ed.), New York, Wiley, ss.71-88.

Blaylock M.J., Huang J.W., (2000), Phytoextraction of Metals, Phytoremediation of Toxic Metals: Using Plants to Clean-up the Environment'1n içinde, (Raskin I., Ensley B.D., Ed.), New York, Wiley, ss.53-70.

Brooks R.R., (Ed.), (1998), Plants that hyperaccumulate heavy metals: their role in phytoremediation, microbiology, archaeology, mineral exploration and phytomining, CAB International, New York, 380ss.

Clemens S., (2006), Toxic metal accumulation, responses to exposure and mechanisms of tolerance in plants, Biochimie, 88(11), 1707-1719.

Ellis D.R., Salt D.E., (2003), Plants selenium and human health, Current Opinion in Plant Biology, 6, 273-279.

EPA, (1995), Contaminants and remedial options at select metals-Contaminated Sites, EPA/540/R-95/512.6

EPA, (2000), Environmental Protection Agency, Introduction of phytoremediation, epa/600/R-99/107, Cincinati, Ohio, U.S.A2000: 72.

Glass D.J., (1999), Economic patential of phytoremediation, Phyforemediation of Toxic Metals: Using Plants to Clean Up the Environment, (Raskin I., Ensley B.D., Eds.), John Wiley\&Sans, New York, ss.15-31.

Glass D.J., (2000), The 2000 Phytoremediation industr, Glass Associates, Needham, MA.

Hamutoğlu R., Dinçsoy A.B., Duman D., Aras S., (2012), Biyosorpsiyon, adsorpsiyon ve fitoremediasyon yöntemleri ve uygulamaları, Türkiye Hijyen ve Deneysel Biyoloji Dergisi 69, 69.

Kabata-Pendias A., Dudka S., (1991), Trace metal contents of taraxacum officinale (Dandelion) As A Convenient Environmental Indicator. Environ. Geochem. And Health. 13(2), 108-113.

Lasat M.M., (2000), Phytoextraction of metals from contaminated soil: A review of plant/soil/metal interaction and assessment of pertinent agronomic issues, Journal of Hazardous substance Research, 2(5), 1-25.

Long X.X., Yang X.E., Ni W.Z., (2002), Current Status and perspective on phytoremediation of heavy metal polluted soils, Journal of Applied Ecology, 13, 757-762.

Milner M.J., Kochian L.V., (2008), Investigating heavy-metal hyperaccumulation using thlaspi caerulescens as a model system, Annals of Botany, 102, 3-13.

Mirsalia, ( 2004), Soil pollution: origin, monitoring and remediation, Springer-Verlag Berlin Heidelberg. 
Newman L.A., Reynolds C.M., (2004), Phytodegradation of organic compounds, Current Opinion in Biotechnology, 15, 225-230.

Niess D.H., (1999), Microbial heavy-metal resistance, Applied Microbiol. Biotech., 51, 730-750.

Favas P.J.C., Pratas J., Varun M., D’Souza R., Poul M.S., (2014), Phytoremediation of soils contaminated with metals and metalloids at mining areas: potential of native flore, Envormental Risk Assessment of Soil Contamination'nın içinde (Hernandez-Soriano M.C., Ed.), InTech Press, ss.485-517.

Raskin I., Smith R.D., Salt D.E., (1997), Phytoremediation of metals using plants to remove pollutants from the environment, Curr. Opin. Birstechnol, 8, 221-226.

Reeves R.D., (2006), Hyperaccumulation of trace elements by plants, Phytoremediation of metal-contaminated soils, NATO Science Series: IV: Earth and Environmental Sciences, (Morel J.L., Echevarria G., Goncharova N. Ed.), Springer, NY, ss.1-25.

Rizzi L., Petruzzelli G., Poggio G., Vigna Guidi G., (2004), Soil physical changes and plant vailability of Zn and Pb in a treatability test of phytostabilization, Chemosphere, 57, 1039-46.

Salt D.E., Rauser W.E., (1995), MgATP-Dependent Transport of phytochelatins across the tonoplast of oat roots, Plant Physiology, 107, 1293-1301.

Söğüt Z., Zaimoğlu B.Z., Erdoğan R., Doğan S., (2002), Su Kalitesinin Arttırılmasında Bitki Kullanımı (Yeşil IslahPhytoremediation), Türkiye'nin Kıyı ve Deniz alanları IV. Ulusal Konferansı, 5-8 Kasım, Dokuz Eylül Üniversitesi, İzmir, Bildiriler Kitab1. II. Cilt, 1007-1016.

Terzi H., Yıldız M., (2011), Ağır metaller ve fitoremediasyon: fizyolojik ve moleküler mekanizmalar, Afyon Kocatepe Üniversitesi Fen Bilimleri Dergisi, 11(2011), 1-22.

Türkoğlu B., (2006), Toprak kirlenmesi ve kirlenmiş toprakların ıslahı, Yüksek Lisans Tezi, Çukurova Üniversitesi, Fen Bilimleri Enstitüsü, Adana.

URL-1, (2006), http://www.edumedia-sciences.com/a420_12-phytoremediation.html, [Erişim 8 Haziran 2006].

Yaldız G., Şekeroğlu N., (2012), Tıbbi ve aromatik bitkilerin bazı ă̆ır metallere tepkisi, Türk Bilimsel Derlemeler Dergisi, 6(1), 8084. 